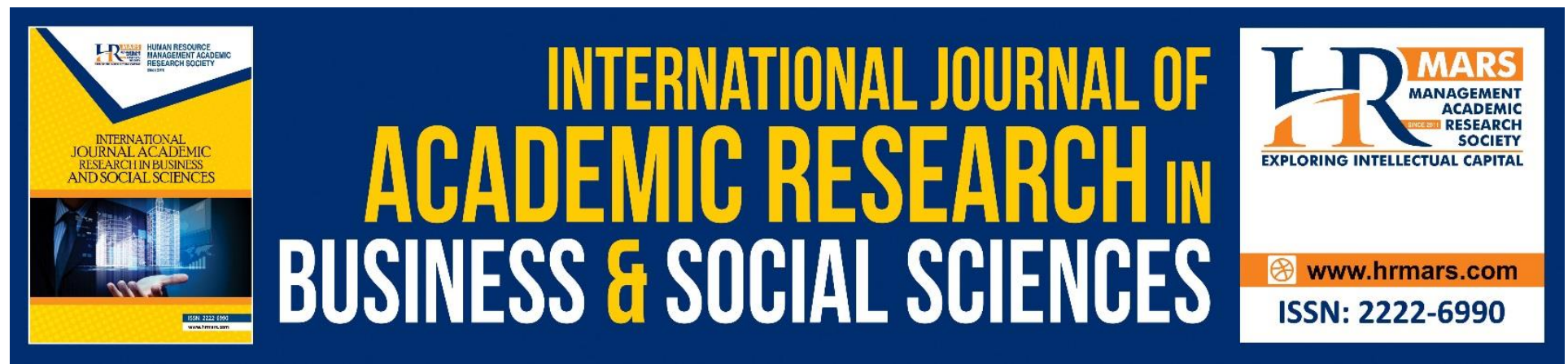

\title{
Tourist Cities Resident's Perceptions on Social Impacts of Tourism Activities
}

\author{
Burhan, Ahmad Mtengwa \\ Janeth Amaniel Malleo
}

To Link this Article: http://dx.doi.org/10.6007/IJARBSS/v9-i1/5414

DOI: $\quad 10.6007 /$ IJARBSS/v9-i1/5414

Received: 29 Dec 2018, Revised: 25 Jan 2019, Accepted: 30 Jan 2019

Published Online: 07 Feb 2019

In-Text Citation: (Burhan \& Malleo, 2019)

To Cite this Article: Burhan, A. M., \& Malleo, J. A. (2019). Tourist Cities Resident's Perceptions on Social Impacts of Tourism Activities. International Journal of Academic Research in Business and Social Sciences, 9(1), 414429.

Copyright: (C) 2019 The Author(s)

Published by Human Resource Management Academic Research Society (www.hrmars.com)

This article is published under the Creative Commons Attribution (CC BY 4.0) license. Anyone may reproduce, distribute, translate and create derivative works of this article (for both commercial and non-commercial purposes), subject to full attribution to the original publication and authors. The full terms of this license may be seen

at: http://creativecommons.org/licences/by/4.0/legalcode

Vol. 9, No. 1, 2019, Pg. 414 - 429

http://hrmars.com/index.php/pages/detail/IJARBSS

JOURNAL HOMEPAGE

Full Terms \& Conditions of access and use can be found at http://hrmars.com/index.php/pages/detail/publication-ethics 


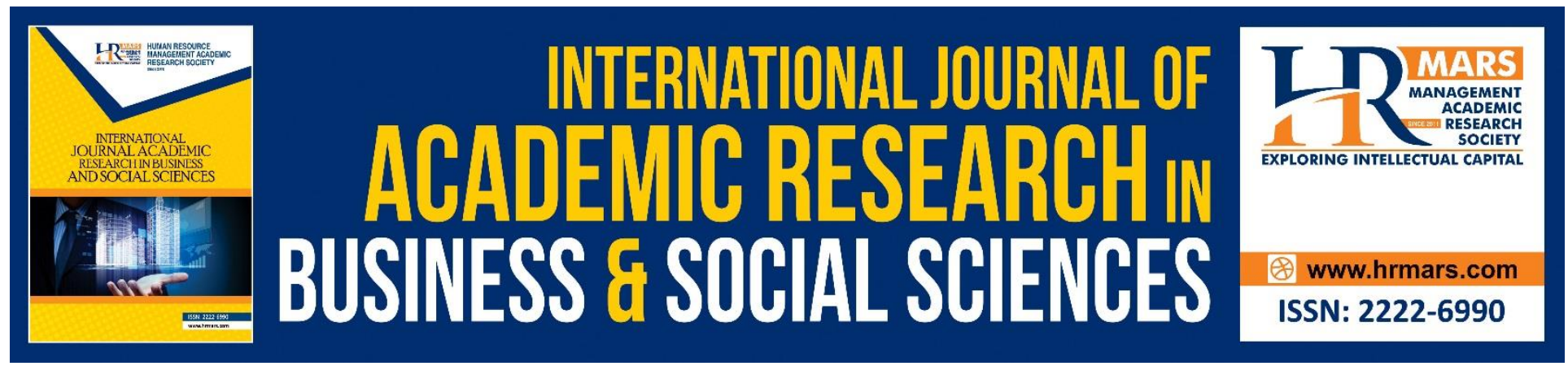

\title{
Tourist Cities Resident's Perceptions on Social Impacts of Tourism Activities
}

\author{
Dr. Burhan, Ahmad Mtengwa \\ Centre for Foreign Relations, Department of Economic Diplomacy, Po Box 2824 Dar es Salaam, \\ Tanzania. \\ Email:mtengwa@hotmail.com

\begin{abstract}
Janeth Amaniel Malleo
Centre for Foreign Relations, Department of Economic Diplomacy, Po Box 2824 Dar es Salaam,

Tanzania.

Email: janee2malleo@gmail.com
\end{abstract}

\begin{abstract}
The study aimed to assess the social impacts of tourism activities on the residents of tourist cities. Both negative and positive impacts of tourism activities were identified. The qualitative method of data collection and data analysis were employed to enable researcher to collect quality data. Primary data were collected from the respondents reside on tourist's cities and presented in a form of essays and other means of descriptive presentation. Then secondary information was applied to collect data through documented source.

The findings shows that there are certain impacts which are, improved their social image, creation of employment and other opportunities, expiation of cultural and make the community more pride.

The research findings concluded, the Uncontrolled convectional tourism poses potential threats on sustainable development in aspects of economic, social and environment to both human and natural ecosystem. The researcher recommend an increase efforts of the responsible institutions on the management of tourist destinations like National parks, museums, historical sites. Also the researcher calls for local community involvement and benefiting on every aspects of tourism development without compromising the ability of the future generations, as well as they should understand the importance of nature of contact between the tourists and them which is highly determined by the level of participation of the communities around the destinations.
\end{abstract}


Keywords: Tourist, Residents, Tourism Activities, Social Impacts

\section{INTRODUCTION}

Tanzania is among many countries in the world which its economy depends more in natural resources utilization such as water, soil, forest, wildlife, land, minerals and other environmental asset in economic activities. Economic activities through natural resources which based on agricultural, Industries, Wildlife (animals), forest (plants), and tourism especially for natural environment such as National Parks, Nature Reserves and other activities to protect fauna and flora, can be done by government sectors or agencies, local organizations, Non-Governmental Organization or Community Based Groups or individuals. Tourism provides valuable revenue, and Tanzania Nation Parks contribute $20 \%$ revenue to the national economy. $7.5 \%$ of it used to support conservation works of the national parks, as well as wildlife research, education and likelihood of local communities (UNREPORT, 2004). The tourism sector in Tanzania is never left behind on the global focus of sustainable tourism for sustainable development. Sustainable tourism refers to a balanced development that satisfies the exigencies and desires of tourist (demand), the exigencies and desires of public and private tourism industry operators (supply) and the protection of the (natural, built, and cultural) (Creaco \& Querini, 2003).

However, tourism sector has adverse impacts on natural, cultural and socio-economic environments of tourism development that threatens the future generations on benefiting from the sector. Social impacts refer mostly to the effects from the direct contact of hosts with tourists. Societies are exposed equally to negative and positive phenomena from tourism. They have been classified as negative when they contribute to disruption of society's components, and as positive when they upgrade vital attributes. Degradation of the environment, crime, alcoholism, drug use, prostitution, gambling, increase of cost of living, and changes on value systems have been ranked at the top of the negative impacts. In contrast, some positive benefits to residents have been noticed, such as the economic gains and the opportunity to enjoy an improved infrastructure resulting from the presence of tourists. Among positive consequences, are the efforts of international peace-keeping associated with tourism, women's emancipation (de Kadt 979:64; Boissevain, 1977), as well as revitalization of traditional dancing, dying arts and ceremonies, which strengthen the culture, employment opportunities, increased welfare, education, ecological protection, etc. (Briassoulis, 1992). Finally, depending on their ability to be measured, impacts are further characterized as direct or indirect and as qualitative or quantitative (Dogan 1989).

The last decades the summer influx of labor and thousands of visitors in total has been disproportionate to the local population size (Coccossis, 1996). The local community can be seriously affected by the various social consequences of a disproportionate tourist ratio and the type of tourists (Milman and Pizam, 1988). The increase of alcoholism, crime, litter, and sound pollution, loss of hospitality, xenophobia and hostility has been noticed in similar situations. Also the observation from Bodlender et al (1991) and Holloway (2002) point out that impact of tourism go father on economic, social cultural and environmental degradation on the community. But report from WTO (1993) points out the impacts of tourism as follows; the 
negative impacts from tourism occur when the level of visitors use is greater than the environments ability to copy with this use within the acceptable limits of change. Community and local leaders have various perceptions on the social impacts of tourism in the community.

Therefore, the purpose of this study was to investigate the Tanzania touristy cites residents' perceptions of the social consequences of tourism both positive and negative ones.

\section{Limitation of the Study}

This study focused only on cities which are regarded as tourists cities due to the presence of tourists attraction. However other cities which tourists pass through either to acquire some services or as an entrance point have not been included. Therefore findings may not translate to other cities reached with tourists for other purpose.

\section{RELATED LITERATURE REVIEW}

Historically, it has been examined that the Arabs, Portuguese, British and other European influences have led to dramatic impacts on socio-cultural aspects in tourism cites. Various researchers have examined the contribution of Islam to the tourism development. The observed conflict between the Islamic laws and tourists with the regard to the dress code. Holton,D. and Al-Katnny,C. (1998) who examine the tourists dress code. For example, women are required to wear a veil whenever they go out in public places while men required wearing pants that reach beyond the knees and shirts with sleeves that reach beyond the elbows. They also sight an increase in the alcohol consumption which had been brought by the development of tourism. Islamic law regards alcohol as 'haram' (forbidden). However the youth now perceive the alcohol consumption as modern progression due to the influence of the tourists who visit in Bagamoyo, Zanzibar district. The importation of alcohol is been looked upon as inevitable to the successful development of tourism in Bagamoyo and Zanzibar towns because most of the Hotels and lodges offers alcohol in their bars and clubs both for tourists and local people. Also observation from Gartner (1993) argues that there are negative impacts of tourism as explained below; Infrastructure costs where by tourism development can cost local government and local people who are tax payers a great deal of money. Development may need the government to improve on roads, airports and other infrastructure and possibly to provide tax breaks and other financial advantages which are costly activities for the government. He further points out that the public resources spent on subsidized infrastructure or tax breaks may reduce government investment in other critical areas like education and health. Increase in price leads to increase in demand for basic services and goods from tourism in increasing proportionately. On other hand Cooper et al (1998) increasing levels of tourists also affect labour, tourism can create jobs, but it can also lead to inflation. They also add that, if taxes received from tourists are used simply to offset local tax burdens and not to plan for tourism development; tourism is more likely to become a tax liability. Kadt (1979) suggest that people who enjoy or suffer the main impacts of tourism are those who live in the communities in the tourism destination. 


\section{RESEARCH METHODOLOGY}

The methodology involved qualitative method of data collection and data analysis, this enabled the researcher to collect quality data, whereby primary data from residents of tourist's cities were collected and presented in form of essays and other means of descriptive presentation. Then secondary information was applied to collect data through documented source.

The objective of the study was designed to clarify the social impact of tourism sector in Tanzania's tourist cities. It is an exploratory research which sought to provide conclusive evidence (Zikmund 1994:13). The sampling frame consisted of a list of over 60 residents of tourist city in Tanzania. A structural survey was used to collect ordinal data and respondents were asked to respond on Liker scale of measurement from 1=strong disagree to $5=$ strong agree. Data were analyzed by using multivariate analysis in order to establish variable which constitute more explanation of the study. The correlation analysis, KMO and factor analysis was done.

\section{RESULT AND DISCUSSION}

Table 1: Composition of the Respondents in Demographic Terms

\begin{tabular}{|c|c|c|c|}
\hline Demographic & Rage & $\mathrm{N}$ (Mean) & Percentage (\%) \\
\hline \multirow[t]{3}{*}{ Gender } & Male & \multirow{2}{*}{1.51} & 24 \\
\hline & Female & & 25 \\
\hline & Total & & 49 \\
\hline \multirow[t]{6}{*}{ Age } & $18-29$ & \multirow[t]{5}{*}{2.33} & 13 \\
\hline & $30-41$ & & 14 \\
\hline & $42-53$ & & 16 \\
\hline & $54-65$ & & 5 \\
\hline & Over 65 & & 1 \\
\hline & Total & & 49 \\
\hline \multirow[t]{9}{*}{ cities } & Arusha & \multirow[t]{8}{*}{3.49} & 19 \\
\hline & Bagamoyo & & 4 \\
\hline & Zanzibar & & 10 \\
\hline & Morogoro & & 0 \\
\hline & Iringa & & 0 \\
\hline & Kilwa & & 2 \\
\hline & Mara & & 10 \\
\hline & Dar Es Salaam & & 4 \\
\hline & Total & & 49 \\
\hline \multirow[t]{6}{*}{ interaction } & Once & \multirow[t]{5}{*}{3.16} & 7 \\
\hline & Twice & & 8 \\
\hline & Thrice & & 12 \\
\hline & More than thrice & & 14 \\
\hline & None & & 8 \\
\hline & Total & & 49 \\
\hline
\end{tabular}

Source: Research findings, 2014 


\section{Variable Description}

There were two main variables in this study namely Positive Influences of Tourism (PTI) and Negative Influences of Tourism (NTI) Since in each variable series of statement was develop to measure respondent perception on social impacts of tourism activities on tourist cities in Tanzania, this justifying of using likert scale is to get an overall measurement of a contributing variable (Likert 1932). Thus perception of residents on tourist cities in Tanzania was measured on ordinal scale level of five-point likert scale i.e., 1=Strongly Agree, 2=Agree, 3=Neutral, 4=Disagree and 5=Strongly Disagree (Bowling 1997 and Burns \& Grove 1997). The study collected primary data from 50 respondents from tourist cities of Arusha, Zanzibar, Morogoro, Iringa, Kilwa, Mara and Dar Es Salaam in Tanzania.

\section{Descriptive Statistics}

According to Trochim, (2006) a descriptive statistics are used to describe the basic features of the data in a study, with the purpose to present quantitative descriptions in simple summaries about the sample and the measures of the study in a sensible way. In descriptive statistics data set a measure commonly by measure of central tendency and measure of variability or dispersion. Babbie (2009) explain further Measures of central tendency include the mean, median and mode while measures of variability include the standard deviation (or variance), the minimum and maximum values of the variables, kurtosis and skewness. From table 3.2 bestow information regarding study variable Positive Influences of Tourism (PTI) and Negative Influences of Tourism (NTI). The data presented in sensible way based on the mean score and standard deviation. Below is the table summary;-

Table 2: Descriptive Statistics for Each Variable

\begin{tabular}{|l|l|l|}
\hline VARIABLE & MEAN & STANDARD DEVIATION \\
\hline Positive Influences of Tourism (PTI) & 14.47 & 9.859 \\
\hline Negative Influences of Tourism(NTI) & 17.30 & 8.03 \\
\hline
\end{tabular}

\section{Correlation and Kaiser-Meyer-Olkin (KMO)}

According to Wang (2000) correlation measure the strength bi-variate linear relationship of the variables. The correlation coefficient for each pair of variables is given by the correlation matrix (R-matrix). The purpose of correlation is to discover if there strong or weak; positive or negative relations between variables. As noted by Hair (2009) the value of correlation can ranges between -1 and +1 . This means that, the values closer to either -1 or +1 indicate either strong negative or positive relationship respectively; also values closer to zero indicate weak relationship. But degrees of caution have to be establishing since problem of multicollinearity may exist, once variables have very strong relationship (Robert 1975 and Ned Kock and Gary S. Lynn (2012). This problem hinders effective estimation in factor analysis. So caution is required in the correlation analysis since correlation is the basis for factor analysis. 
INTERNATIONAL JOURNAL OF ACADEMIC RESEARCH IN BUSINESS AND SOCIAL SCIENCES

Vol. 9, No. 1, Jan, 2019, E-ISSN: 2222-6990 @ 2019 HRMARS

Table 3; Correlation Matrix for Ministered Variable

\begin{tabular}{|c|c|c|c|c|c|c|c|c|c|c|c|c|c|c|c|}
\hline \multicolumn{8}{|c|}{ Positive Influences of Tourism (PTI) } & \multicolumn{8}{|c|}{ Negative Influences of Tourism (NTI) } \\
\hline & PTI1 & PTI2 & PTI3 & PTI4 & PTI5 & PTI6 & PTI7 & & NTI1 & NTI2 & NTI3 & NTI4 & NTI5 & NTI6 & NTI7 \\
\hline PTI1 & & .000 & .000 & .000 & .000 & .000 & .494 & NTI1 & & .000 & .001 & .019 & .000 & .001 & .002 \\
\hline PTI2 & .000 & & .000 & .000 & .000 & .000 & .472 & NT2 & .000 & & .003 & .092 & .000 & .001 & .002 \\
\hline PTI3 & .000 & .000 & & .000 & .000 & .000 & .372 & NTI3 & .001 & .003 & & .000 & .001 & .000 & .001 \\
\hline PTI4 & .000 & .000 & .000 & & .000 & .000 & .487 & NTI4 & .019 & .092 & .000 & & .002 & .000 & .000 \\
\hline PTI5 & .000 & .000 & .000 & .000 & & .000 & .431 & NTI5 & .000 & .000 & .001 & .002 & & .000 & .000 \\
\hline PTI6 & .000 & .000 & .000 & .000 & .000 & & .200 & NTI6 & .001 & .001 & .000 & .000 & .000 & & .000 \\
\hline PTI7 & .494 & .472 & .372 & .487 & .431 & .200 & & NTI7 & .002 & .002 & .001 & .000 & .000 & .000 & \\
\hline
\end{tabular}

Source: Researcher's field data analysis, 2014.

In above matrix clusters of variables with high intercorrelations are represented, these clusters of variables could well be "manifestations of the same underlying variable" (Rietveld \& Van Hout 1993: 255). Refer to factor analysis correlation matrix for all manifested variable have to be generated, also they have to be intercorrelated but they should not correlate too highly (extreme multicollinearity and singularity) as this would cause difficulties in determining the unique contribution of the variables to a factor to other and last the correlation coefficients greater than 0.3 in absolute value are indicative of acceptable correlations (Field 2000: 444). Results demonstrated that the correlation coefficients among the observed variables regarding Positive Influences of Tourism (PTI) and Negative Influences of Tourism (NTI) indicates that no variables which are highly correlated that can bring in the problem of extreme multicollinearityat determinant 0.00001 (Field 2000: 445).

Table 4: KMO and Bartlet Test for Ministered Variable

\begin{tabular}{|l|l|r|r|}
\hline \multicolumn{2}{|l|}{ KMO and Bartlett's Test } & \multicolumn{1}{l|}{ PTI } & \multicolumn{1}{l|}{ NTI } \\
\hline $\begin{array}{l}\text { Kaiser-Meyer-Olkin Measure of Sampling } \\
\text { Adequacy. }\end{array}$ & KMO & 0.905 & 0.824 \\
\hline Bartlett's Test of Sphericity & & & \\
\cline { 2 - 4 } & Approx. Chi-Square & 201.141 & 173.059 \\
\cline { 2 - 4 } & Df & 21 & 21 \\
\cline { 2 - 4 } & Sig. & 0.000 & 0.000 \\
\hline
\end{tabular}

Source: Researcher's field data analysis, 2013.

Kaiser-Meyer-Olkin (KMO) measures sampling adequacy. It value ranges between 0 and 1 . A value close to 0 indicates that the factor model will be inappropriate while a value closer to 1 will indicate the factor model is appropriate. Generally, KMO values greater than 0.5 are acceptable otherwise there is a need of expanding the sample size (Kaiser and Rice 1974). In our analysis KMO value are Positive Influences of Tourism (PTI) 0.905 and Negative Influences of Tourism (NTI)0.824, which is fear and we are sure that our factor analysis model is appropriate. 
INTERNATIONAL JOURNAL OF ACADEMIC RESEARCH IN BUSINESS AND SOCIAL SCIENCES

Vol. 9, No. 1, Jan, 2019, E-ISSN: 2222-6990 @ 2019 HRMARS

As initiated by Bartlett (1937), Bartlett's test of sphericity is used to test the existence of an identity matrix in our correlation matrix. This identity matrix occurs when each pair of variables indicates zero correlation. Thus, if we reject the null hypothesis which states that the correlation matrix is an identity, then our factor model will be correct. Table 3.5 show that there is intercorrelation on manifested variable which has significance value of 0.000 for Positive Influences of Tourism (PTI) and 0.000 for Negative Influences of Tourism (NTI). This means that the test was significant value of 0.000 is less than 0.05 thus, factor analysis will be applicable for our data.

\section{Reliability Measure of Variables}

Any research based on measurement must be concerned with the accuracy or dependability. In this study a likert survey instrument were used, it is essential to discern that the instrument have to be elicit consistent and reliable response even if were replaced with other similar questions. Such kind of instrument which generated from such a set of questions that return a stable response, then your variable is said to be reliable. As noted by Thorndike, Cunningham, Thorndike, \& Hagen, (1991) reliability refers to the accuracy and precision of a measurement procedure. Reliability comes to the forefront when variables developed from summated scales are used as predictor components in objective models. It is a function of properties of the underlying construct being measured, the test itself, the groups being assessed, the testing environment, and the purpose of assessment. The measurement of reliability in Cronbach's alpha is an index of reliability associated with the variation accounted for by the true score of the underlying construct (Hatcher, 1994). As developed by Cronbach, (1951). Alpha coefficient ranges in value from 0 to 1 and may be used to describe the reliability of factors extracted from dichotomous. The higher the score, the more reliable the generated scale is. Nunnaly (1978) and Welman and Kruger (2001:141), has indicated 0.7 to be an acceptable reliability coefficient but lower thresholds are sometimes used in the literature, but other scholar such as (Jos,Chen\& Lim 20009;988;Zidmund,Babin,Carr \&Griff 2010) argue that acceptable levels of reliability depend on the purpose of the instrument and research purposes can be as low as 0.60. However as noted by Parasuraman et al (1985) that in some situation where by a diagnostic instrument used for making decisions about individuals for instance a psychological measure Cronbach alpha should be much higher as 0.95 .

Table 5; Cronbach's Alpha Reliability Measure for All Variables

\begin{tabular}{|l|r|r|r|}
\hline Variables & N of Items & N of observations & Cronbach's Alpha \\
\hline $\begin{array}{l}\text { Positive Influences of } \\
\text { Tourism(PTI) }\end{array}$ & 7 & 48 & 0.498 \\
\hline $\begin{array}{l}\text { Negative Influences of } \\
\text { Tourism(NTI) }\end{array}$ & 7 & 48 & 0.872 \\
\hline Overall Alpha & $\mathbf{1 4}$ & $\mathbf{4 8}$ & $\mathbf{0 . 7 8 9}$ \\
\hline
\end{tabular}

Source: Researcher's field data analysis, 2014. 
INTERNATIONAL JOURNAL OF ACADEMIC RESEARCH IN BUSINESS AND SOCIAL SCIENCES

Vol. 9, No. 1, Jan, 2019, E-ISSN: 2222-6990 (C) 2019 HRMARS

Table 5 above provides the Cronbach's alpha for each observed variable regarding challenges facing procurement functions in Tanzania. The overall Cronbach's alpha coefficient is 0.789 indicating a good reliability.

\section{Component Factor Analysis}

Factor analysis is a multivariate statistical technique for data reduction. It compresses sets of complex data without losing data integrity, to form reduced set of factors, which are assumed to represent the observed variables under consideration. Gorsuch (1983:4) mote that factor analysis helps reduce a number of variables to a meaningful, interpretable and manageable set.. In this study factor analysis will be used to establish whether the variables: Positive Influences of Tourism (PTI) and Negative Influences of Tourism (NTI)Therefore, all factor loadings must be statistically significant at a minimum to confirm the discriminant validity of the measuring instrument used in the study. In this study, the sample size was 50 which are confirmed by Camrey and Lee (1992), Garson (2008) and Noruis (2005) in terms of the factor analysis sample size rule on number of constrain. In this study, the principalcomponent exploratory factor analysis with the support of statistical package SPSS 17.0 was adopted so as to obtain sound and clean solutions for our problem. Below is the table 3.6 shown result of factors analysis.

Table 6; Factor Loadings on Perception of touristy cities residence

\begin{tabular}{|c|c|c|c|}
\hline \multirow[t]{2}{*}{ Latent Variable } & \multicolumn{3}{|c|}{ Component Factor Analysis } \\
\hline & \multirow{2}{*}{$\begin{array}{l}\text { Factor } 1 \\
\text { Tourism for Social Development }\end{array}$} & Factor 2 & \multirow[t]{2}{*}{ Communalities } \\
\hline $\begin{array}{l}\text { Positive Influences of } \\
\text { Tourism (PTI) }\end{array}$ & & $\begin{array}{l}\text { Tourism for Sex } \\
\text { business }\end{array}$ & \\
\hline PTI1 & 0.844 & & 0.714 \\
\hline PTI2 & 0.856 & & 0.733 \\
\hline PTI3 & 0.875 & & 0.772 \\
\hline PTI4 & 0.891 & & 0.794 \\
\hline PTI5 & 0.885 & & 0.784 \\
\hline PTI6 & 0.808 & & 0.687 \\
\hline PTI7 & & 0.992 & 0.985 \\
\hline \multirow{2}{*}{$\begin{array}{l}\text { Negative Influences of } \\
\text { Tourism(NTI) }\end{array}$} & Factor 1 & Factor 2 & \\
\hline & Disrupting social value & Social living & \\
\hline NTI1 & & 0.855 & 0.781 \\
\hline NTI2 & & 0.919 & 0.863 \\
\hline NTI3 & 0.801 & & 0.713 \\
\hline NTI4 & 0.898 & & 0.809 \\
\hline NTI5 & & 0.769 & 0.739 \\
\hline NTI6 & 0.808 & & 0.764 \\
\hline NTI7 & & & 0.553 \\
\hline
\end{tabular}

Source: Researcher's field data analysis 2014. 
The component factor analysis result shown in table 3.7 revealed that six of the seven item (PTI1, PTI2, PTI3, PTI4, PTI5, and PTI6) expected to measure positive influence of tourism have been loading in factor one (1) This means that respondents viewed these items as measure of a single construct renamed as and labeled Tourism for Social Development. Also communalities on all variables are considered to be more that $60 \%$. Observation from residence from Tanzania's tourist cities viewed tourism for Social Development as predicated on a number of factors in particular, consideration should be given to the impact that tourism has on the community as a whole and the individuals who make up that community. This has been shared by Faulkner \&Tideswell (1997) he noticed that the impacts of tourism require some monitoring in order to protect community wellbeing, and to ensure the long term viability of the tourism product. However Pearce (1998) argue that the community in tourist cities, as hosts to tourists, is vital in the visitor experience and may affect tourism development by its willingness, or otherwise, to be involved in the tourism. Finding of the study revealed that community in tourist cities tourism industry has enhance their local economy, improved their social image, creation of employment and other opportunities, expiation of cultural and make the community more pride. This finding were also observed observe in other study Ahn, Lee \&Shastudyfer (2002), Twinning-Ward \& Butler 2002, McCool, Moisey\& Nickerson (2001) and ursoy, Jurowski\&Uysal (2002).

The component factor analysis result shown in table 3.7 reveals that only one of the seven item (PTI7) expected to measure positive influence of tourism have been loading in factor two (2) This means that respondents viewed these items as measure of a single construct renamed as and labeled Tourism for sex business. Also communalities on all variables are considered to be more that $60 \%$. Observation from residents of tourist cities in Tanzania indicated that there were number of men (and women) travelled to their cities for sexual purposes. Sex or erotic tourism may be defined as tourism for which the main motivation or at least part of the aim of the trip is to consummate or engage in commercial sexual relations (Graburn 1983; Hall 1991; Ryan and Hall 2001; Truong 1990). This findings was also Observed with (Herold et al. 2001; Ryan and Hall 2001) where they noticed the increases of sex tourism in world. However In the past, notorious destinations for sex tourism have been mainly the Southeast Asian countries such as Bangkok ('the red light capital of the world'), Thailand (sometimes called 'Thighland'), the Philippines, Indonesia, South Korea and Sri Lanka (Enloe 2002; Hall 2001; Lim 1998; Robinson and Bishop 1998). Today, sex tourism has spread to other regions of the world including Goa (a coastal state of India), Cuba, the Dominican Republic, Brazil, Costa Rica, Eastern Europe and a number of African countries such as Kenya, Tunisia, South Africa and The Gambia (Ryan and Hall 2001, Enloe 2002; Chissim 1996;). Studies show that not only male engage in sex tourism but also female as noted by Chissim (1996), Ryan and Hall (2001) Pruitt and LaFont (1995) in which they indicate how female tourists in Jamaica engage in sex tourism but in reality men make up the majority of sex tour customers (Abu-Nasr, 1998). Finding revealed that in all tourist city in which a study have been carried sex tourism has been increased tremendously. However residents count it as an economic opportunity despites the danger of highly spread of sexually transmitted diseases (STD).

The component factor analysis result shown in table 3.7 revealed that three of the seven item (NTI3, $\mathbf{N T I 4 , a n d ~ N T I 6 ) ~ e x p e c t e d ~ t o ~ m e a s u r e ~ p o s i t i v e ~ i n f l u e n c e ~ o f ~ t o u r i s m ~ h a v e ~ b e e n ~ l o a d i n g ~ i n ~ f a c t o r ~ o n e ~}$ 
(1) This means that respondents viewed these items as measure of a single construct renamed as and labeled Disrupting social value. Also communalities on all variables are considered to be more that $60 \%$. Observation from residence on Tanzania tourist cities tourism often disrupts social at destinations, research notice that in most tourist cities crime activities has been emerge if not increase. Crime in tourist city can have this situation for instance as notice by (Walmsley, Boskovic and Pigram (1981) concentration of tourists increases the persons and property at risk in an area and therefore possibly makes that area more attractive to criminal elements within the population of the city. Similarly, tourist areas are characterized by anonymity and a high turnover of population with a result that it may well be easy for criminals to conceal themselves and avoid apprehension, particularly when the police have to cope with massive increases in the volume of traffic (and increases in other forms of "routine" work unrelated to crime) associated with seasonal peaks in the tourist industry. The study observed that crime in tourism city can be approach in three dimensions firstly those crime against tourist, crime against tourist attraction and crime against community in tourism cities. This finding has been justified with the study of Jud (1975), Pizam (1999) Ferreira and Harmse (2000) in South Africa and Harper (2001). Father study observed that because of crime activities there is possibility of disrupted the peace and tranquility in Tourist cities. Lastly observation is on increased litter in the streets and public places in Tourist cities especially in the area where public awareness is very little on environment issues.

The component factor analysis result shown in table 3.7 revealed that three of the seven item (NTI1, NTI2 and NTI5) expected to measure positive influence of tourism have been loading in factor two (2) This means that respondents viewed these items as measure of a single construct renamed as and labeled Social living. Also communalities on all variables are considered to be more that $60 \%$. Observation from residence on Tanzania tourist cities tourism made people to adopt foreign words in their daily vocabulary, increased extremely real estate costs and living in Tourist cities.

\section{CONCLUSION AND RECOMENDATIONS}

The tourism development has economic, social, environmental and cultural impacts to the nearby community in terms of culture of people, economic transformation and environmental degradation. The negative impacts from tourism occurred when the level of visitors use is greater than the environments ability to copy with this use within the acceptable limits of change. Uncontrolled convectional tourism poses potential threats to the Mother Nature around the world. It can put enormous pressure on an area and lead to impacts such as soil erosion, increased pollution, discharges in to the sea, natural habit loss. The most important benefits of tourism in its best form are that it can be significant vehicle for achieving concentration of the environment and cultural heritage of the areas. Therefore tourism as an economic sector it should provide place to experience culture traditions and norms of local community while ensuring sustainability of environment.

The management of tourist destinations like National parks, museums, historical sites should be improved. Local community should understand the importance of nature of contact between the tourists and the communities around which determined by the level of participation of the communities around the destinations. Local communities must be involved in planning, decision making and implementation of any tourism development projects and must benefit from it. These 
INTERNATIONAL JOURNAL OF ACADEMIC RESEARCH IN BUSINESS AND SOCIAL SCIENCES

Vol. 9, No. 1, Jan, 2019, E-ISSN: 2222-6990 (C) 2019 HRMARS

will avoid conflict between tourist or managements of tourist sites and local people or residents and brings community awareness on the effects of tourism as well as avoiding new culture adoption from tourists and maintain and praise their local culture.

This research is significant since it is measure individual insights on social impact of tourism. The study will add to the existing knowledge on impacts of tourism by considering opinions of community who lives in tourist cities.

\section{REFERENCES}

Abu-Nasr, D. (1998). Sex Tour' Industry Growing in U.S. The Associated Press. Retrieved January 15, 2002, from http://www.aegis.com.

Ahn, B., Lee, B. \& Shafer, C.S. (2002) 'Operationalising Sustainability in Regional Tourism Planning: An Application of the Limits of Acceptable Change Framework.' Tourism Management. 23: 1-15.

Babbie, E. (2009). Conducting qualitative field research. In The practice of social research (11th ed.). U.S.A.: Thomson Wadsworth.

Bishop, R. and Robinson, L.S. (1998). Night Market: Sexual cultures and the Thai Economic Miracle, London and New York: Routledge.

Bodlender, J., Jefferson, A., Jenkins, C. \& Lickorish, L. (1991) Developing Tourism Destinations:

Policies and Perspectives. Longman, Harlow.

Boissevain, J. (1979) The Impact of Tourism on a Dependent Island: Gozo, Malta; Annals of Tourism Research 6(1):76-90

Bowling, A. (1997) Research Methods in Health. Open University Press, Buckingham

Briassoulis, H. 1992 Environmental Impacts of Tourism: A framework for analysis and evaluation,In: van der Straaten, J. and Briassoulis, H. (eds) Tourism and the Environment: Regional, Economic and Policy Issues. Kluwer Academic Publishers, Dordrecht.

Burns, N. \& Grove, S.K. (1997) The Practice of Nursing Research Conduct, Critique, \& Utilization. W.B. Saunders and Co., Piladelphia

Camrey, A.L. \& Lee, H.B. (1992). A first course in factor analysis. Hillsdale, NJ: Erlbaum.

Chissim F. (1996). An exploratory and Descriptive Research on Child Prostitution and Tourism in Kenya. EPAT Report, Nairobi.

Coccossis, H. (1996): Tourism and Sustainability: Perspectives and Implications; In: G.K Priestley J.A. Edwards - H. Coccossis eds.: Sustainable Tourism ? European Experiences; CAB International, Oxon, UK, pp.1-21 
INTERNATIONAL JOURNAL OF ACADEMIC RESEARCH IN BUSINESS AND SOCIAL SCIENCES

Vol. 9, No. 1, Jan, 2019, E-ISSN: 2222-6990 (C) 2019 HRMARS

Cooper, C. (1999), Tourism Principles and Practices, Addison Wesley Longman Publishing, New York, p-124-182.

Creaco, S. \& Querini G (2003). The Role of Tourism in Sustainable Economic Development

Cronbach, L.J. (1951), "Coefficient Alpha and the Internal Structure of Tests," Psychometrika, 16, 297-334.

De Kadt, E., (1979) Social Planning for Tourism in the Development Countries, Annals of Tourism Research,

Dogan, H. Z. (1989) Forms of Adjustment: Sociocultural Impacts of Tourism Annals of Tourism Research 16: 216-236

Enloe, C. (2002). The prostitute, the colonel and the Nationalist, in: Enloe, Cynthia: Maneuvers: The international politics of militarising women's lives: London and Los Angeles: University of California Press (2nd Edition) pp 19-41

Faulkner, B. \& Tideswell, C. (1997) 'A Framework for Monitoring Community Impacts of Tourism.' Journal of Sustainable Tourism, 5 (1): 3-28.

Ferreira, S., \& Harmse, A. (2000). Crime and tourism in South Africa: International tourist perception and risk. South African Geographical Journal, 82(2), 80-85.

Field, A. P. (2000). Discovering statistics using SPSS for Windows: Advanced techniques for the beginner. London: Sage.

Garson, D. G. (2008). Factor Analysis: Statnotes. Retrieved March 22, 2008, from North Carolina State University Public Administration Program, http://www2.chass.ncsu.edu/garson/pa765/factor.htm

Gartner W.C., (1987) "Environmental impacts of recreational home developments", Annals of tourism research, Volume 10. No.2

Gorsuch, R.L. 1983. Factor analysis. 2nd edition. Hillsdale, NJ: Erlbaum.

Gursoy, D., Jurowski C., \& Uysal, M. (2002). A structural modeling of resident's attitudes toward tourism. Annals of Tourism Research, Vol. 29, No. 1, pp.79-105.

Hall, C. M. (1994). Nature and Implications of Sex tourism in South-East Asia in: V. H. Kinnaird and D. R. Hall (ed) Tourism: A Gender Analysis Chichester, John Wiley PP-142-163

Harold, E., Garcia, R. \& DeMoya, T. (2001). Female tourists and beach boys: romance or sex tourism? Annals of Tourism Research, 28 (4): 978-997.

Harper, D. W. (2001). Comparing tourists' crime victimization. Annals of Tourism Research, 28(4), 1053-1056. 
INTERNATIONAL JOURNAL OF ACADEMIC RESEARCH IN BUSINESS AND SOCIAL SCIENCES Vol. 9, No. 1, Jan, 2019, E-ISSN: 2222-6990 (C) 2019 HRMARS

Hatcher, L. (1994). A step-by-step approach to using the SAS(R) system for factor analysis and structural equation modeling. Cary, NC: SAS Institute.

Holloway, J.C. (1998) The business of tourism , Addison Wesley Longman, Harlow

Joseph f. Hair, jr,william c. Black,barry j. Babin, and rolph e. Anderson (2009) Multivariate data analysis, Pearson., upper saddle river boston columbus san francisco

Jud, D. G. (1975). Tourism and crime in Mexico. Social Science Quarterly, 56(2), 324-330.

Kaiser, H.F. (1974). An index of factorial simplicity. Psychometrika, 39, 31-36.

Kock, Ned and Lynn, Gary S. (2012) "Lateral Collinearity and Misleading Results in Variance-Based SEM: An Illustration and Recommendations," Journal of the Association for Information Systems: Vol. 13: Iss. 7, Article 2.

Available at: http://aisel.aisnet.org/jais/vol13/iss7/2

Likert, R. (1932). A technique for the measurement of attitudes. Archives of Psychology, 22(140), 155.

Lim, Lean Lin (1998). Whither the sex sector? Some policy considerations University of California press, pp 49-108.

McCool, S.F., Moisey, R.N., and Nickerson, N.P. (2001) 'What should tourism sustain? The disconnect with industry perceptions of useful indicators.' Journal of Travel Research, 40(4): 124131.

Michael, Robert T. (1975) "Education and Consumption" in ed. F. Thomas Juster Education, Income, and Human Behavior (New York: McGraw-Hill): 235-252.

Milman A., Pizam A., (1988) Social Impacts of Tourism on Central Florida Annals of Tourism Research 15:191-204

Noruis, M.J. (2005). SPSS 13.0 Statistical procedures companion. Chicago: SPSS, Inc.

Nunnally, J.C. (1978), Psychometric Theory, McGraw-Hill Book Company, New York, NY.

Parasuraman, A., Zeithaml, V. A., and Berry, L. L. (1985). A conceptual model of service Quality and its implications for future research, Journal of Marketing, Vol. 49,P.41-50.

Pearce, P. (1998) The relationship between residents and tourists: the research literature and management directions. In Global Tourism, W. Theobald, ed., pp. 129-149. Oxford: ButterworthHeinemann.

Pearce, P. (1998) The relationship between residents and tourists: the research literature and management directions. In Global Tourism, W. Theobald, ed., pp. 129-149. Oxford: ButterworthHeinemann. 
INTERNATIONAL JOURNAL OF ACADEMIC RESEARCH IN BUSINESS AND SOCIAL SCIENCES

Vol. 9, No. 1, Jan, 2019, E-ISSN: 2222-6990 (C) 2019 HRMARS

Pizam, A. (1999). A comprehensive approach to classifying acts of crime and violence at tourism destinations. Journal of Travel Research, 38(1), 5-12.

Pruitt, D. and Lafont, S. (1995) For Love and Money: romance tourism in Jamaica, Annals of Tourism research 22(2); $419-440$.

Rietveld, T. and Van Hout, R. (1993) Statistical techniques for the study of language and language behaviour. Berlin: Mouton de Gruyter.

Ryan Chris and Hall C Michael (2001): Sex Tourism: Marginal People and Liminalities

Thorndike, R. M., Cunningham, G. K., Thorndike, R. L., \& Hagen E. P. (1991). Measurement and evaluation in psychology and education. New York: Macmillan Publishing Company.

Trochim, (2006 Trochin., W.M.K. 2006. Research methods knowledge base. [Onliine]. Available: www.socialresearchmethods.net [Accessed: September 2011]

Truong, T. D. (1990). Sex, Money and Morality. Prostitution and Tourism in Southeast Asia. Zed books Ltd. London and New York

Twining-Ward, L. \& Butler, R. (2002) 'Implementing STD on a Small Island: Development and Use of Sustainable Tourism Development Indicators in Samoa'. Journal of Sustainable Tourism, 10(5): 363387.

Walmsley, D. J., Boskovic, R. M., \& Pilgram, J. J. (1981). Tourism and crime. Armidale, NSW: University of New England.

Welman, J.C. \& Kruger, S.J. (2001) (2nd edition). Research Methodology for the Business and Administrative Science. Cape Town: Oxford University Press.

WTO, (1993) Sustainable Tourism Development: A guide for Local Planners

Zikmund, G.W. (1994). Business research methods. 4th edtion. Florida USA: The Dryden press.

Zikmund, W. G., Babin, B. J., Carr, J. C. \& Griffin, M. (2010). Business research methods. 8th edition. Singapore: South-Western Cengage Learning. 